\title{
Perinatal mortality of placenta previa: a 1-year retrospective study
}

\author{
Shibram Chattopadhyay ${ }^{1}$, Siddhartha Majumder ${ }^{1 *}$, \\ Kajal Kumar Patra ${ }^{2}$, A. H. Mostafa Kamal ${ }^{1}$
}

\begin{abstract}
${ }^{1}$ Department of Obstetrics and Gynecology, Nil Ratan Sircar Medical College and Hospital, Kolkata, West Bengal, India

${ }^{2}$ Department of Obsetrics and Gynaecology, Bankura Sammilani Medical College, Bankura, West Bengal, India
\end{abstract}

Received: 16 November 2018

Accepted: 01 December 2018

\section{*Correspondence:}

Dr. Siddhartha Majumder,

E-mail: siddharthamajumder5@gmail.com

Copyright: (C) the author(s), publisher and licensee Medip Academy. This is an open-access article distributed under the terms of the Creative Commons Attribution Non-Commercial License, which permits unrestricted non-commercial use, distribution, and reproduction in any medium, provided the original work is properly cited.

\begin{abstract}
Background: Antepartum haemorrhage is one of the important causes of perinatal mortality and morbidity in India. The increased risk of perinatal morbidity and mortality in placenta praevia is due to preterm birth, low birth weight, birth asphyxia and neonatal sepsis. This is a retrospective study done over a period of 5years to determine the incidence, demographic features, risk factors, obstetric management, maternal mortality and morbidity, and perinatal outcome in women presenting with placenta praevia.

Methods: This was a retrospective study done at Nil Ratan Sircar Medical College and Hospital over a period of five years starting from January 2016 to December 2017. Antenatal women with more than 28 weeks of gestational age with a complaint of painless vaginal bleeding or those diagnosed as having placenta praevia on routine ultrasound examination were included in this study and hospitalised. Among them cases of placenta praevia were 21 .

Results: There were 21 cases of placenta praevia registered amounting to $0.23 \%$ incidence. The various antenatal complications seen associated with placenta praevia were severe anaemia (14.28\%), coexisting PIH (4.76\%), IUD $(4.76 \%)$, IUGR/Oligohydraminos $(4.76 \%)$. All the patients in the study had undergone caesarean deliveries. Perinatal morbidity studied as percentage of new-borns requiring resuscitation followed by NICU admission was $33.3 \%$. Among the delivered patients of placenta praevia incidence of perinatal mortality was $23.8 \%$. Prematurity $(42.85 \%)$ contributed to most cases of perinatal mortality, followed by RDS (14.28\%) and asphyxia (14.28\%).

Conclusions: In this study placenta praevia is seen more commonly in 28-34 weeks of gestation and patients mainly presented with a bout of bleeding eventually had preterm deliveries. Although vaginal deliveries are appropriate in selected cases of placenta paevia liberal use of caesarean section in well-equipped hospitals with availability of blood transfusion services have helped to lower complications.
\end{abstract}

Keywords: Antepartum haemorrhage, Asphyxia, Perinatal mortality, Placenta praevia, Prematurity

\section{INTRODUCTION}

Placenta praevia is the localisation of a placenta in the lower segment of uterus, over or near the internal cervical os. ${ }^{1}$ The reported incidence for placenta praevia is 1 case per 300-400 deliveries. ${ }^{2}$ Antepartum haemorrhage complicates $3-5 \%$ of pregnancies and is a leading cause of perinatal and maternal mortality worldwide. ${ }^{3}$ Risk factors include high parity, advancing maternal age, previous caesarean section and uterine surgery. ${ }^{4}$

Antepartum haemorrhage is one of the important causes of perinatal mortality and morbidity in India. ${ }^{5}$ Placenta praevia is an abnormal placentation where the placenta is 
situated in the lower uterine segment either covering the internal os or just touching it. It is one of the major causes of antepartum haemorrhage, complicating $2-5 \%$ of pregnancies. $^{6}$

The increased risk of perinatal morbidity and mortality in placenta praevia is due to preterm birth, low birth weight, birth asphyxia and neonatal sepsis.

Risk factors of placenta praevia are advancing maternal age, multiparity, previous caesarean section, curettage for previous abortion, increased incidence of multiple pregnancies (with big placenta) because of increased ART.

The prevalence of placenta praevia has been rising in parallel with the increasing rate of caesarean delivery and it has become a serious public health problem worldwide..$^{7,8}$

This is a retrospective study done over a period of 5years to determine the incidence, demographic features, risk factors, obstetric management, maternal mortality and morbidity, and perinatal outcome in women presenting with placenta praevia.

\section{METHODS}

This was a retrospective study done at Nil Ratan Sircar Medical College and Hospital over a period of five years starting from January 2016 to December 2017. Total number of deliveries was 8,776 during this period.

\section{Inclusion criteria}

- Antenatal women with more than 28 weeks of gestational age with a complaint of painless vaginal bleeding or those diagnosed as having placenta praevia on routing ultrasound examination were included in this study and hospitalized.

Among these cases the cases of placenta praevia were 21 . Records of all those women who had caesarean deliveries for placenta praevia including both emergency and planned operations were reviewed and findings were noted.

\section{RESULTS}

There were a total of 8,776 deliveries from January 2016 to December 2017.

Among them 21 cases of placenta praevia were registered amounting to the incidence of $0.23 \%$.

As mentioned in table 1 majority of the patients were unbooked $(76.19 \%)$. Placenta praevia cases were highest in the age group $20-30$ years $(85.71 \%)$ in multiparous patients $(76.19 \%)$.
Table 1: Demographic profile.

\begin{tabular}{|l|l|l|l|}
\hline \multicolumn{1}{|c}{} & \multicolumn{1}{|c|}{$\begin{array}{l}\text { Number of } \\
\text { patients }\end{array}$} & Percentage \\
\hline \multirow{2}{*}{$\begin{array}{l}\text { Booking } \\
\text { status }\end{array}$} & Booked & 5 & 23.8 \\
\cline { 2 - 4 } & Unbooked & 16 & 76.19 \\
\hline \multirow{3}{*}{ Age } & 19 & 2 & 9.52 \\
\hline \multirow{2}{*}{ Parity } & $20-30$ & 18 & 85.71 \\
\hline & $31-40$ & 1 & 4.76 \\
\hline & Primigravida & 5 & 23.80 \\
\hline & Multigravida & 16 & 76.19 \\
\hline
\end{tabular}

In Table 2 the most common gestational age at the time of presentation was $28-34$ weeks $(52.38 \%)$. In $66.66 \%$ of cases presenting symptom was antepartum haemorrhage.

Table2: Obstetric evaluation.

\begin{tabular}{|c|c|c|c|}
\hline & & $\begin{array}{l}\text { No. of } \\
\text { patients }\end{array}$ & $\%$ \\
\hline \multirow{2}{*}{$\begin{array}{l}\text { Gestational } \\
\text { age at the } \\
\text { time of } \\
\text { presentation }\end{array}$} & 28-34 weeks & 11 & 52.38 \\
\hline & $\begin{array}{l}35 \text { weeks to } \\
\text { term }\end{array}$ & 10 & 47.61 \\
\hline \multirow{2}{*}{$\begin{array}{l}\text { Antepartum } \\
\text { haemorrhage }\end{array}$} & Present & 14 & 66.66 \\
\hline & Absent & 7 & 33.33 \\
\hline \multirow{3}{*}{$\begin{array}{l}\text { Presentation } \\
\text { of foetus }\end{array}$} & Cephalic & 18 & 85.71 \\
\hline & Breech & 2 & 9.52 \\
\hline & Transverse & 1 & 4.76 \\
\hline \multirow{4}{*}{$\begin{array}{l}\text { Previous } \\
\text { obstetric } \\
\text { performance }\end{array}$} & Primigravida & 7 & 33.33 \\
\hline & $\begin{array}{l}\text { Vaginal } \\
\text { delivery }\end{array}$ & 5 & 23.80 \\
\hline & $\begin{array}{l}\text { Caesarean } \\
\text { delivery }\end{array}$ & 7 & 33.33 \\
\hline & Abortion & 2 & 9.52 \\
\hline
\end{tabular}

In $85.71 \%$ patients the presenting part of the foetus was cephalic and the most common placental location by radio diagnosis or intraoperatively was type $2(38.09 \%)$, according to table 3 . The most common obstetric risk factor for placenta praevia was primigravida (33.33\%) and previous caesarean deliveries $(33.33 \%)$.

Table 3: Location of placenta by USG and intraoperative findings.

\begin{tabular}{|l|l|l|}
\hline Types & Number & $(\%)$ \\
\hline Type1 & 3 & 14.28 \\
\hline Type2 & 8 & 38.09 \\
\hline Type3 & 6 & 28.57 \\
\hline Type4 & 4 & 19.04 \\
\hline
\end{tabular}

According to table 4 the various antenatal complications seen associated with placenta praevia were severe anaemia (14.28\%), coexisting PIH (4.76\%), IUD (4.76\%), IUGR/Oligohydraminos (4.76\%). All the patients in the study had undergone caesarean deliveries. Intraoperative complications seen were post-partum haemorrhage (23.8\%) and shock/ Hypotension (4.76\%). 
Table 4: Antenatal, intraoperative and post-operative complications.

\begin{tabular}{|c|c|c|c|}
\hline \multicolumn{2}{|c|}{ Complications } & \multirow{2}{*}{$\begin{array}{l}\text { No. of } \\
\text { patients } \\
3\end{array}$} & \multirow{2}{*}{$\begin{array}{l}\% \\
14.2 \\
8\end{array}$} \\
\hline \multirow{4}{*}{ Antenatal } & Severe anaemia & & \\
\hline & Coexisting PIH & 1 & 4.76 \\
\hline & IUD & 1 & 4.76 \\
\hline & $\begin{array}{l}\text { IUGR/ } \\
\text { Oligohydraminos }\end{array}$ & 1 & 4.76 \\
\hline \multirow{2}{*}{$\begin{array}{l}\text { Intraoperati } \\
\text { ve and post- } \\
\text { operative }\end{array}$} & $\begin{array}{l}\text { Shock/ } \\
\text { Hypotension }\end{array}$ & 1 & 4.76 \\
\hline & PPH & 5 & 23.8 \\
\hline
\end{tabular}

There were no cases of associated gestational diabetes mellitus and complications such as sepsis, febrile morbidity, adherent placenta or acute kidney injury seen. There was no maternal mortality in this study.

Table 5 shows that perinatal morbidity studied as percentage of newborns requiring resuscitation followed by NICU admission was $33.3 \%$. Among the delivered patients of placenta praevia incidence of perinatal mortality was $23.8 \%$. Prematurity $(42.85 \%)$ contributed to most cases of perinatal mortality, followed by RDS $(14.28 \%)$ and asphyxia (14.28\%). Perinatal deaths were observed more in $27.27 \%$ of 11 premature deliveries that took place in 28-34 weeks of gestation. New-born with weight above $2 \mathrm{~kg}$ had very good survival rates, whereas with weight $1 \mathrm{~kg}$ had poor survival rates.

Table 5: Neonatal outcome.

\begin{tabular}{|c|c|c|c|}
\hline \multicolumn{2}{|c|}{ Parameters } & $\begin{array}{l}\text { No. of } \\
\text { patients }\end{array}$ & Percentage \\
\hline \multicolumn{2}{|c|}{ NICU Admission } & 7 & 33.33 \\
\hline \multirow{5}{*}{$\begin{array}{l}\text { Neonatal } \\
\text { mortality }\end{array}$} & Asphyxia & 1 & 14.28 \\
\hline & Prematurity & 3 & 42.85 \\
\hline & IVH & 0 & 0 \\
\hline & RDS & 1 & 14.28 \\
\hline & Total & 5 & 23.80 \\
\hline
\end{tabular}

\section{DISCUSSION}

The incidence was amounting to $0.23 \%$ which is similar to various other studies that shown incidence of placenta praevia to vary from $0.33 \%$ to $0.38 \% .{ }^{9,10}$ Most of the patients in this study (76.19\%) are unbooked and include those patients who do not have regular antenatal checkups and those that are referred. Increasing age and number of pregnancies have been shown to be an important risk factor for placenta praevia. This study had majority of patients in the age group 20-30 years $(85.71 \%)$ and almost three fourths of the patients were multigravidas $(76.91 \%)$ which is similar to the study done by Rajeshwari RR et al with $79.9 \%$ patients belonging to $20-30$ years age group and $75 \%$ of patients as multigravidas. ${ }^{11}$
Regarding previous obstetric history, $33.33 \%$ had previous LSCS and $33.33 \%$ were primigravidae, $23.8 \%$ had previous vaginal deliveries while $9.52 \%$ had history of abortion. This is similar to study done by Lavanyakumari Sarella et al with risk factors such as previous LSCS (40\%), primigravida (34.42\%) previous vaginal deliveries $(29.5 \%)$ and previous abortions $(9.83 \%)$. Previous history of abortions have been significantly associated with up to three times risk of placenta praevia. $^{12}$ Majority of the patients were multigravidas $(76.19 \%)$ as seen in study done by Lavanyakumari Sarella et al $(65.57 \%)$ and Rajeshwari RR et al $(75.5 \%) .{ }^{12}$

In this study placenta praevia is seen more commonly in 28-34 weeks of gestation $(52.38 \%)$ which is similar to other studies. ${ }^{12,13}$ Among them they mainly presented with a bout of bleeding $(66.66 \%)$ followed by preterm delivery on several occasions.

Complications that occurred in the antenatal period such as severe anaemia (14.28\%), pregnancy induced hypertension $(4.76 \%)$, intrauterine death $(4.76 \%)$, intrauterine growth retardation or oligohydraminos $(4.76 \%)$ were similar to the study done by Rajeshwari RR et al with but the intraoperative and post-operative complications included only postpartum haemorrhage $(23.8 \%)$, shock and hypotension $(4.76 \%){ }^{11}$

Neonatal morbidity was significant in present study and more before 34 weeks of gestation as $33.33 \%$ patients required NICU admission. A population based retrospective cohort study among singleton mother-infant pairs $(n=544,734)$ showed that the association between low birth weight and placenta praevia is chiefly due to preterm delivery and to a lesser extent because of foetal growth restriction. ${ }^{6}$

In present study perinatal mortality was $23.80 \%$ which was similar to the study done by S Singhal et al (23.7\%) but less than the study done by Arora et al (61.5\%) and Khosla et al $(53.5 \%){ }^{14,5,15}$

\section{CONCLUSION}

Although placenta praevia cannot be prevented the extent of maternal and perinatal morbidity and mortality can be reduced by spacing pregnancies, limiting family size, antenatal registration of all pregnancies, routine ultrasonography in pregnancies and early referral of highrisk pregnancies to tertiary care centres. In this study majority of the patients were from rural areas and were unaware of the importance of antenatal visits. Advancing maternal age, multiparity, prior caesarean section, and prior abortions are independent risk factors for placenta praevia. An increase in the incidence of these risk factors probably contributes to a rise in the number of pregnancies complicated with placenta praevia. 
In this study placenta praevia is seen more commonly in 28-34 weeks of gestation and patients mainly presented with a bout of bleeding eventually leading to preterm deliveries. Although vaginal deliveries are appropriate in selected cases of placenta praevia liberal use of caesarean section in well-equipped hospitals with availability of blood transfusion services have helped to lower complications.

\section{Funding: No funding sources}

Conflict of interest: None declared

Ethical approval: The study was approved by the Institutional Ethics Committee

\section{REFERENCES}

1. Philip N Barker, Obstetrics Ten Teachers, publication book power, edition 18th Antenatal Ostetrical Complication, 2006;125-8.

2. Cunningham FG, Leveno KJ, Bloom SL, Spong CY, Dashe JS, Hoffman BL, Casey BM, Sheffield JS. Obstetrícia de Williams. McGraw Hill Brasil; 2016:801

3. Calleja-Agius J, Custo R, Brincat MP, Calleja N. Placental abruption and placenta praevia. Eur Clin Obstet Gynaecol 2006;2(3):121-7.

4. Sinha P, Kuruba N. Anteparum haemorrhage: an update. J Obstet Gynecol. 2008;28(4):377-81.

5. Arora R, Devi U, Majumdar k. Perinatal morbidity and mortality in antepartum Haemorrhage. J Obstet Gynae India 2001;51(3):102-4.

6. Ananth CV, Wilox AJ, Cavitz DA, Bowes WA Jr, Luther ER. Effect of maternal age and parity on risk of uteroplacental bleeding in pregnancy. Int J Obstet and Gynecol. 2006;2(4):511-6.

7. Downes KL, Hinkle SN, Sjaarda LA, Albert PS, Grantz KL. Previous prelabor or intrapartum caesarean delivery and risk of placenta previa. Am J Obstet Gynecol.2015;212(5)669.
8. Cresswell JA, Ronsmans C, Calvert C, Filippi V. et al, Prevalence of placenta previa by world region: a systemic review and meta-analysis. Trop Med Int Health. 2013;18(6):712-24.

9. Sheiner E, Shoham-Vardi I, Hallak M, Hershkowitz R, Katz M, Mazor M. Placenta Previa: obstetric risk factors and pregnancy outcome. J Maternal-Fetal Neonat Medi.2001;10(6):414-19.

10. Crane JM, Van den Hof MC, Dodds L, Armson BA, Liston R. Maternal complications with placenta previa. Am J Perinatol. 2000;17(2):101-5.

11. Rajeshwari RR, Rubini M. Maternal and perinatal outcome in placenta previa -one-year study in tertiary care center in Tamil Nadu, India. Int J Reprod Contracept Obstet Gynecol. 2016;5(8):281922.

12. Lavanyakumari Sarella, Arunajyothi; A Study Onmaternal and Perinatal Outcome in Placenta Previa. Schol J App Med Sci. 2014; 2(5A):1555-8.

13. Tyagi P, Yadav N, Sinha P,Gupta U. Study of antepartum haemorrhage and its maternal and perinatal outcome. Int $\mathbf{J}$ Reprod Contracept Obstet Gynecol. 2016;5(11):3972-7.

14. S Singhal, Nymphaea, S Nanda. Maternal and Perinatal outcome in Antepartum haemorrhage: A study at tertiary care referral institute. Inter $\mathbf{J}$ Gynaecol Obstet: 2013; 9(2):5580.

15. Khosla A, Dahiya V, Sangwan K, Rathore S. Perinatal outcome in antepartum hemorrhage. J Obstet Gynae India. 1989;9:71-3.

Cite this article as: Chattopadhyay S, Majumder S, Patra KK, Kamal AHM. Perinatal mortality of placenta previa: a 1-year retrospective study. Int J Reprod Contracept Obstet Gynecol 2019;8:31-4. 